\title{
Heading for Retirement? National Insurance, State Pensions, and the Future of the Contributory Principle in the UK
}

\author{
JOHN HILLS \\ Director, ESRC Research Centre for Analysis of Social Exclusion (CASE), \\ London School of Economics \\ email: j.hills@/se.ac.uk
}

\begin{abstract}
This article discusses the implications of the decline of National Insurance in Britain, witnessed by its declining share of social security spending and steady dilution of the 'contributory principle' on which it was originally based. This decline is not accidental: under governments of the Left, arguments for inclusion have predominated, non-contributory benefits expanded and contribution conditions softened; under those of the Right, limited resources have been focused on the poorest through means-testing. From this starting point, the strong arguments in principle for social insurance look much weaker. However, there are also reasons why the system has not been swept away, notably the way in which most of it concerns already accrued state pension rights.

The effect of current plans for state pensions is to restore something closer to a flat rate state pension, but with significant complexity. The article suggests a way in which a more transparent system could guarantee a total state pension at a fixed percentage of average earnings. Other National Insurance benefits could either be separated from pensions and absorbed within other working age social security, or the scope of National Insurance could be maintained, but based on a test of participation, not past contributions.
\end{abstract}

\section{Introduction}

This article examines whether Britain's National Insurance system has a future. Around $\mathfrak{E} 64$ billion was collected in 2002-03 through National Insurance Contributions and $\mathfrak{E}_{74}$ billion in $2003-04$. More than $\mathfrak{E}_{6}$ in every $\mathfrak{E}_{100}$ of national income goes through the National Insurance system, making it as important within the public finances as paying for the National Health Service.

Large parts of the system still rest - albeit with substantial later modification on the foundation of Beveridge's 1942 report, Social insurance and allied services. His plan was for a comprehensive scheme of what he firmly saw as insurance to cover the main contingencies which led to Want in the 1930s: unemployment, sickness and old age. It was based on flat-rate contributions leading to flat-rate benefits. In that way it was not redistributive, but, as it worked through a national pool, those at low risk did subsidise those generally poorer people at high risk, 
unlike private insurance. The system was work-based: if in work, you paid the 'stamp'; if you lost work, you got benefit. As Beveridge put it:

Benefit in return for contributions, rather than free allowances from the State, is what the people of Britain desire... Payment of a substantial part of the cost of benefits as a contribution irrespective of the means of the contributor is the firm basis of a claim to benefit irrespective of means. (Beveridge, 1942: para. 21)

Over the last 60 years, many others have argued powerfully for and have eloquently defended the principles of social insurance. The article starts with a summary of some of the key arguments. This is followed by a recapitulation of the current structure of National Insurance, a brief discussion of why the system has ended up in this form, and the implications of these arguments for its future development. The article then looks in more detail at how state pensions - which account for five-sixths of all national insurance benefits - have developed, and are now planned to develop. It discusses some issues raised by these developments, and an alternative to them. It concludes by discussing the implications for National Insurance as a whole of such changes.

The fundamental questions posed in the article are why, given the strength of the arguments which have been put for a National Insurance system, is it in fact in such decline and, given this decline, where should we go from here? More than 60 years after the Beveridge Report, which led to the post-War National Insurance system, should it be heading for retirement?

\section{What is National Insurance?}

Given the widespread lack of popular understanding, it may be helpful to summarise the main features of National Insurance:

- Its key characteristic is that it is a contributory system, with special taxes National Insurance Contributions (NICs) - paying for the benefits paid out. It is the main example of earmarking or 'hypothecation' in the UK public finances.

- Beveridge's idea of flat rate, Poll Tax-style contributions was abandoned in the early 1960 s and contributions are today based on a percentage of earnings

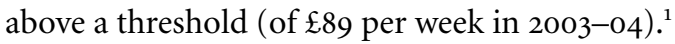

- The overwhelming bulk of the spending is on pensions: five-sixths of National Insurance benefits spending in 2003-04 were on the flat rate state pension or earnings-related additions to it. But contributory benefits also include Widows Pensions, Incapacity Benefit, Jobseeker's Allowance (for up to six months nowadays) and maternity allowances. ${ }^{2}$ These differ from other benefits in that they are dependent both on a particular contingency and on someone having a satisfactory 'contributions record'. 
- When people have been asked what NICs pay for, they suggest 'hospitals or the NHS' first, with most mentioning pensions as well (Stafford, 1998). In fact, less then a tenth of NICs have actually gone towards the NHS in recent years (although the proceeds from the increases in contributions in April 2003 will contribute to rising NHS spending).

- Originally, National Insurance was funded from three sources: employees, employers, and the State. It was this combination which allowed Lloyd George to promise workers 'ninepence for fourpence' when the original, more limited, version of National Insurance started in 1911. The Treasury Supplement was phased out in the 1980s. It made a brief reappearance in the mid-199os, but today NI benefits are paid for entirely by contributions - indeed, the so-called 'National Insurance Fund' runs a surplus and is likely to continue to do so (but the net effect is a contribution to general government revenues rather than accumulation of funds genuinely walled off from the rest of the public finances).

\section{The contributory principle}

The heart of Beveridge's system was straightforward: those who pay in contributions when at work are then entitled to benefits when out of work or retired. This is what the 'contributory principle' meant. Under the strongest kind of contributory principle, in private insurance, the contributions (premiums) made are actuarially linked to the potential value - allowing for individual risk and life expectancy - of the benefits. Under social insurance of the Bismarckian kind in countries such as Germany and France, risks are pooled but there is still a strong link between contributions and benefits in that both are earnings-related. Those who pay in more because of higher earnings at work are then entitled to higher pensions or benefits when unemployed.

The UK system has evolved with a weaker contributory principle: contributions are mostly earnings-related, but benefits are now mostly flat rate (apart from the state second pension - what used to be called SERPS - and, as explained below, that is also becoming less earnings-related than it was). In theory, making contributions is still what gives benefit entitlement:

- Except for those disqualified despite contributions, for instance: those who have not paid in for enough years to get the pension; or who did not contribute enough in the last two tax years before the benefit year in which a claim begins; or if entitlement has run out, for instance after six months on Jobseeker's Allowance; or if claiming Incapacity Benefit while getting other pensions (in which case it will be cut back by half of these).

- And, people can be 'credited in' without making actual contributions for the first two years of education after 16; or if caring for a child or disabled person; or - recently for maternity allowance - if earning over $\mathfrak{£}_{3}$ o per week, well below 
the contributions threshold; or, more generally since 2001, if earning above the old 'Lower Earnings Limit', but below the more generous new 'primary threshold' for contributions.

What we have is in fact a very weak contributory principle: benefits mainly depend on the fact of having made contributions, but people can receive 'contributory benefits' without having made contributions, and can be ruled out of entitlement despite having made contributions.

Why has the British system ended up like this? There are, after all, very strong arguments for social insurance, as opposed to other kinds of benefits, and ones that have proved enduring in continental systems and for what is in fact the largest part of the US benefits system:

- They are a manifestation of social solidarity, through their pooling of risks an argument that proved very popular at the height of the Second World War as the Beveridge Report was published.

- Benefits come as a right, as a result of paying contributions. As Titmuss put it, 'One fundamental historical reason for the adoption of the principle was the aim of making services available and accessible to the whole population in such ways as would not involve users in any humiliating loss of status, dignity or self-respect' (2001: 117). As a consequence, not only is life better for the recipients, but it should also mean higher take-up and hence greater effectiveness in preventing poverty than stigmatised benefits that people fail to claim.

- Because they depend on a contingency such as old age or unemployment rather than a means-test, disincentives to additional self-provision are minimised. ${ }^{3}$

- It is in origin a work-based system. This has two sides to it. The entitlements boost the return to formal, declared work (or at least, offset the resultant taxes and contributions). Also, as Atkinson (1995) has argued, the existence of unemployment insurance can be seen historically as a form of subsidy to employment in the industrial sector, and as improving the working of the industrial labour market.

Finally, there may be greater willingness - or at least less reluctance - to pay contributions for a clear purpose like this than taxes into a general pool. The word 'may' is important here: what evidence there is of public attitudes suggests that people do not make a very big distinction between contributions and other taxes (Stafford, 1998; Hedges and Bromley, 2001). The word 'clear' may also be important: as Hedges and Bromley put it, 'it may be that the less [National Insurance] is thought to be dedicated to Health and Social Security, the more it is seen as just another tax.' 


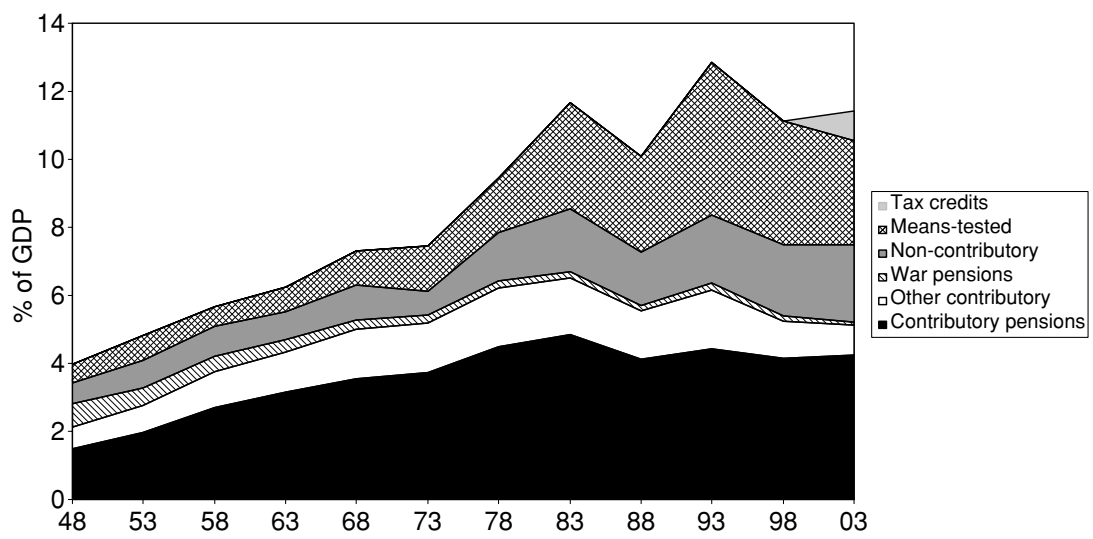

Figure 1. Social security benefits 1948/9-2003/4.

Source: DWP Benefit Expenditure Tables (http://www.dwp.gov.uk/asd/asd4/expenditure/asp).

\section{What has happened to National Insurance?}

So what has happened to the scope of National Insurance since the postWar system was established in 1948? Contributions in 2003-04 represented about 6.5 per cent of national income. Contributory benefits in 2003-04 are forecast to be just over 5 per cent of national income. As Figure 1 shows, this is down from their peak of 6.5 per cent of national income 20 years ago. But more strikingly, contributory benefits and pensions are a much smaller share of the total than they used to be. The growth in social security as a share of GDP in the last 20 years has come from a combination of non-contributory contingency-based benefits (such as extra costs benefits for disabled people) and means-tested benefits. At their peak in the 1960s and 1970s contributory benefits accounted for 70 per cent of all social security spending. They are now less than 45 per cent of the total.

This has happened for several reasons. One is the decline in the relative value of contributory benefits. Compared to average earnings, the basic state pension has been falling pretty well continuously since its peak in 1979, and what used to be Unemployment Benefit for longer, since its link to the pension ended in 1973. But the thresholds for means-tested benefits have not fallen as fast in relative terms. In 1978, the single basic pension was 24.7 per cent of average full-time earnings, and the means-tested minimum (then called Supplementary Benefit) for most single pensioners was 25.2 per cent. Apart from the important complications of Housing Benefit, only a small amount of other income could carry someone clear of the sharpest means-testing. By 2002 the basic pension had fallen to $16.2 \mathrm{per}$ cent of average earnings ( $\mathfrak{L}_{465}$ per week in April 2002 for full-time adult workers), but what was then the Minimum Income Guarantee (MIG) was 21.1 per cent of them. There was a much larger gap to get over to get clear of the MIG. As a result, 
many recipients of contributory benefits also receive a means-tested top-up for instance, one in seven of those getting the basic pension had it topped up by Income Support in 2001. For them, the contributory benefits make no difference to their incomes.

But this has not been the only issue. The story of the last 55 years (from the very start, and the differences between what was actually implemented and Beveridge's recommendations) has been one of only a few battles won for the contributory principle that is supposedly at the heart of National Insurance, but of many more lost. ${ }^{4}$ When decisions have been made about the future development of social security, few have reinforced the idea of a system based around National Insurance benefits linked in any strong way to past contributions. The failure of the 1997-1998 Minister for Welfare Reform, Frank Field, to convince the Treasury under New Labour to revitalise contributory benefits may well have represented the last battle for the contributory principle in the UK.

The introduction of the State Earnings-Related Pension Scheme (SERPS) from 1978 did try to re-establish a strong link between what were by then earningsrelated contributions and subsequent benefits. However, it came 20 years too late to create an embedded system seen as the main source of income replacement for middle and higher income groups, of a kind which has resulted in the strong political defence of continental social insurance schemes. By the late 1950s, one third of those at work were already covered by occupational pension schemes. When mildly earnings-related ('graduated') state pensions were introduced in 1961, members of such schemes were allowed to 'contract out' in return for lower contributions. This principle was carried over into SERPS, arguably the key factor in the system's later lack of resilience when its generosity was cut back in the 1980s, and its structure altered in the late 1990s. As Clasen argues, contrasting the British case with other European social insurance systems:

the decline of the contributory principle in Britain would be difficult to comprehend without recourse to the role of earnings-related transfers. Essentially, because of the poverty rather than wage-replacement orientation, there is a much weaker incentive structure for contributors (employees and employers) to be involved in matters of social insurance (2001: 651).

This pattern, of 'contributory' benefits becoming less related to contributions and declining in importance as a share of social security spending, is not accidental. When governments of the Left have been in power, arguments in favour of inclusion have been predominant, non-contributory benefits have been expanded, and contribution conditions have been softened to 'credit in' people with low earnings or interrupted work histories. When governments of the Right have been in power, particularly in the 1980s, contribution conditions have been made tougher and the emphasis has been on focusing limited resources on the poorest through means-testing. New Labour, interestingly, has done both. 


\section{Should the system survive?}

In the light of this history, the five arguments summarised above for contributory benefits now look distinctly battered:

- The solidarity argument applied to rights based on full-time work is undermined by the reality of today's labour market and society. If rights depended only on work records, many would be excluded; hence the expansion of 'crediting in' within National Insurance and of non-contributory contingencybased benefits to avoid this.

- The complexity of the system and the obscurity of many conditions make it hard to describe the system as embodying clearly understood rights.

- For many, contributory benefits are too low to avoid the need for means-tested top-ups.

- The links to work records and actual contributions are in fact so weak that it is hard to argue for strong labour market effects from people's recognition of the rights earned through contributions. ${ }^{5}$ New Labour's ideology could have been consistent with a revitalised work-based system, but this is a road that has not been taken.

- There is little link between contributions and benefits, either at the individual or the aggregate level, and the links that exist are incomprehensible to most. Contributions are not in reality earmarked, and there is no truly separate National Insurance Fund. If people are less unhappy about paying National Insurance than income tax, that is more a product of folk memory than of current reality.

There is an apparently obvious conclusion: National Insurance has outlived its usefulness and should be swept away (Dilnot et al., 1984; Webb, 1994). In its place we could either integrate National Insurance Contributions with income tax in a much cleaner, more rational system, or reconstitute them as a Social Security Tax. As far as benefits are concerned, the job could be completed of replacing them with either inclusive contingency-based benefits or, depending on ideological taste, means-tested ones.

But while the arguments for a reinvigorated contributory system have decisively lost the policy argument in recent years, the arguments for putting the system out of its misery have not succeeded either. There are reasons for this as well:

- First, despite the low level of public understanding of the system, there does appear to be a relatively strong popular commitment to the basic idea that there is a system which you pay into, and then have rights to benefits from (Stafford, 1998). 'National Insurance' is still a good brand name.

- The majority of what the welfare state as a whole does is in fact this kind of redistribution across people's life cycles rather than between people on a 
lifetime basis (Falkingham and Hills, 1995). Titmuss (1955) once described the public finances as being like Crewe junction, with traffic (transfers) in many directions, rather than like a simple terminus with one-way one-dimensional flows from rich to poor. There is thus much to be said for a system that conveys this idea. Given the imperfection of the system, this is close to saying that the system is a myth, but a useful myth for the population to believe in. Clasen even concludes that, 'too much transparency might have a counterproductive effect in terms of diminishing rather than increasing legitimacy and support' (2001: 655). But if a clearer, more honest, contract could be salvaged, encapsulating the life cycle principle might be a point in favour of the system.

- Most concretely, the bulk of the system is about pensions. Reinforcing the notion that people pay into pension systems to accumulate later rights has fundamental advantages. More practically, people already have accumulated rights to both the basic and earnings-related pension. Governments have been very reluctant to renege on such rights (as opposed to changing the rules for future accumulation). Such rights can persist for $70-80$ years. As we shall see below, adapting them is a very slow process.

- Fourth, almost the only part of the tax system that registers publicly is the basic rate of income tax. It is hard to see a government of any persuasion agreeing to absorption of NICs into income tax, and a rise of 11 or 24 points in the basic rate. Some form of separately labelled tax mimicking NICs will survive any reform.

- Fifth, within the EU, migrant workers enjoy reciprocal rights to various benefits and pensions. Many of these rest on being an 'EU worker', as witnessed by contributions into the more strongly contribution-based systems in other member states. We need some system that allows such reciprocal rights both for British workers elsewhere, and for other nationals working here.

- Finally, unless we were to move entirely to a means-tested system, benefits based on contingency would have to meet some other test. Would UK residence be enough, so those spending the rest of their lives elsewhere could arrive and receive, for instance, equal pension treatment to those who have 'paid in' all their lives? If not, would citizenship be the criterion? But if so, who would be excluded despite paying in?

\section{State pensions now and in future}

Given these conflicting arguments, where might we go? Titmuss (1955) described Beveridge as being a better guide to the 1930s than to the 1950s. He is unlikely to be a perfect guide to the twenty-first century either, but some of his principles may help. One may be his commitment to flat rate benefits rather than meanstested ones (which are lower for those with other income) or earnings-related ones (which are higher for those who had higher earnings). As Table 1 shows, 
TABLE 1. Public attitudes to benefits and earnings, 2001.

\begin{tabular}{lcccr}
\hline & \multicolumn{4}{c}{$\begin{array}{c}\text { Benefits for a very high earner compared } \\
\text { to a very low earner should be: }\end{array}$} \\
\cline { 2 - 5 } & Higher & Same & Lower & None \\
\hline Unemployment benefit & 10 & 76 & 10 & 2 \\
State retirement pension & 13 & 74 & 9 & 3 \\
Disability benefits & 4 & 67 & 21 & 5 \\
Child benefit & 1 & 55 & 23 & 18 \\
\hline
\end{tabular}

Source: Park et al. (2002) based on British Social Attitudes survey.

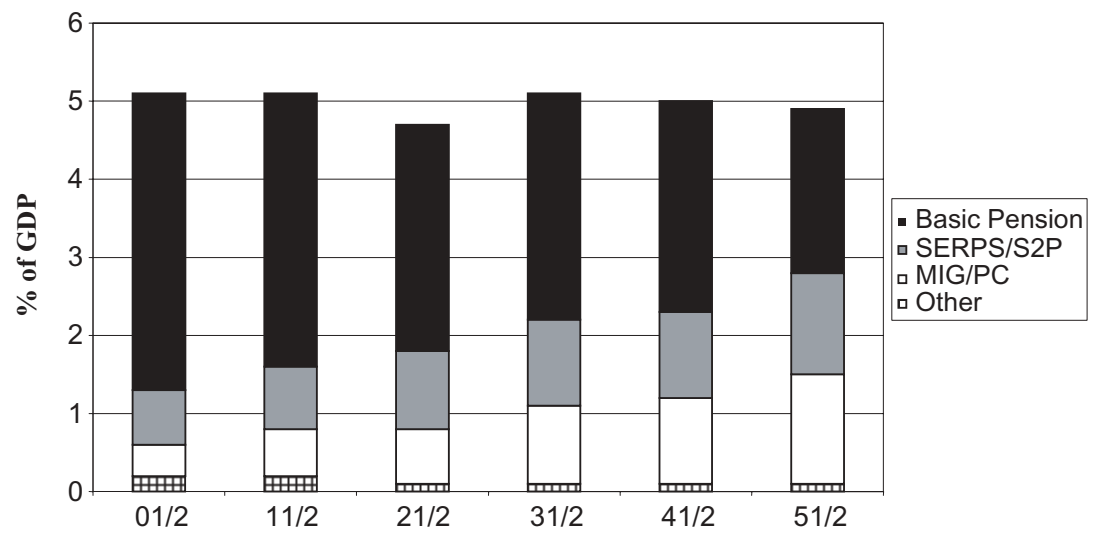

Figure 2. Forecast government spending on pensions.

Source: DWP (2002).

the public appears strongly committed to the idea of flat rate benefits. ${ }^{6}$ This is particularly true of pensions and unemployment benefits. At the same time, people consistently see the state pension as being too low: not one of the retired respondents to the 2000 British Social Attitudes survey thought it was even a bit 'on the high side'; half thought it was 'very low' (Hills, 2001).

As providing state pensions is five-sixths of what National Insurance benefits do, it is worth examining how they are now planned to evolve. First, Figure 2 shows the government's forecast of the share of national income to be spent on state pensions of different kinds over the next fifty years. ${ }^{7}$ What is remarkable is that the total is almost constant, at around 5 per cent of GDP, throughout the period despite the forecast that the ratio of the population over 65 to that aged 15 to 64 will rise from 25 per cent in 2000 to 39 per cent in 2050 (DWP, 2002). It contrasts greatly with other European countries, as shown in Figure 3.

This is achieved through a series of reforms whose long-run impact is perhaps poorly understood. First, Figure 4 shows a very simplified version of how things 


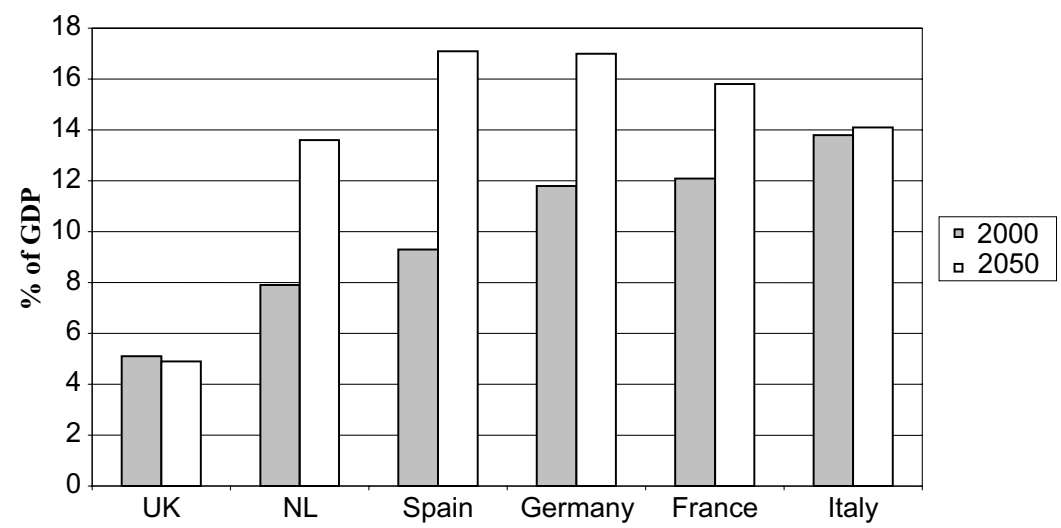

Figure 3. Public pension spending in selected EU countries.

Source: HM Treasury (2002).

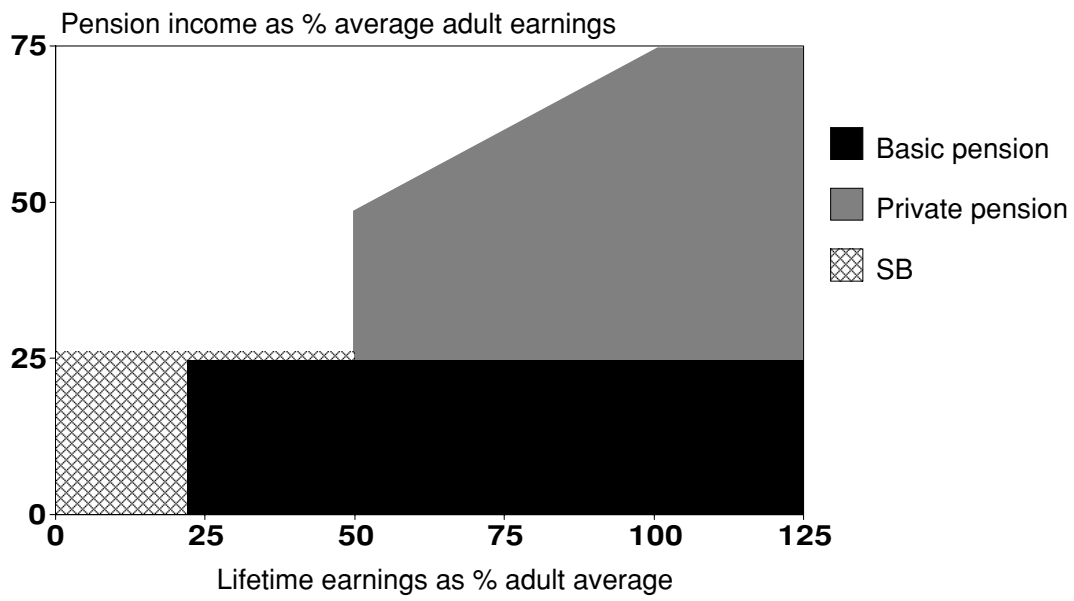

Figure 4. Retiring in 1978.

were in 1978, a position which Beveridge would have recognised. The diagram shows - as do those that follow - the position of a single person with roughly equal earnings (as a proportion of the contemporary adult average) throughout his or her working life. ${ }^{8}$ Someone retiring in 1978 with a good work record at most levels of earnings over the previous 30 years would have received the flat rate basic state pension, then just under a quarter of average adult full-time earnings. On top would come any private pension they might be entitled to. At any given earnings level, some would be entitled to a private pension, others not. As drawn, the diagram shows the case where those with half average lifetime earnings or more could receive a private pension of half their own average earnings. In fact 


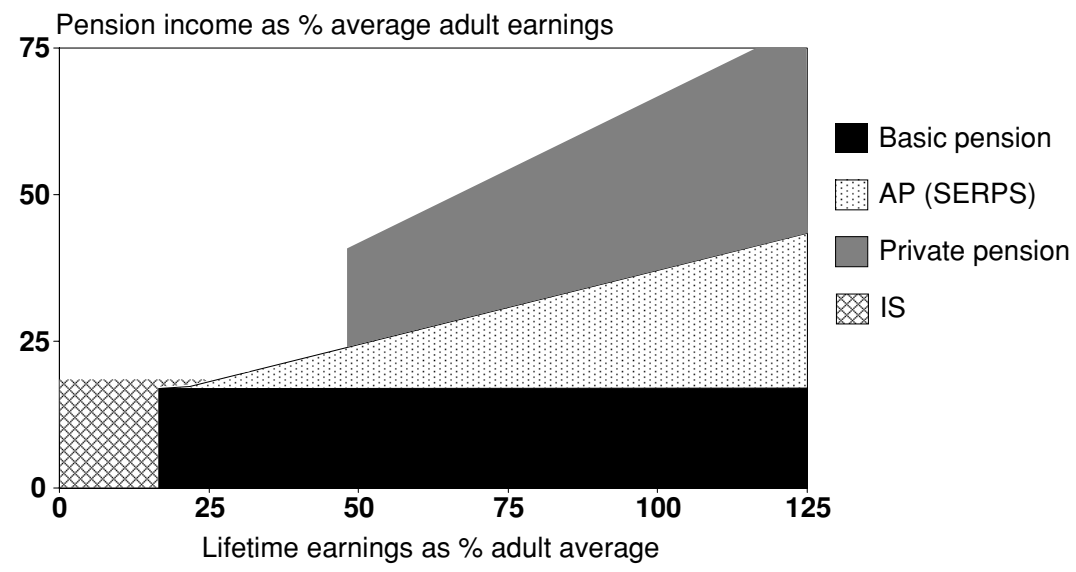

Figure 5. Retiring in 1998.

many lower paid workers paid just above this level would not in fact receive such a pension, but most of those with nearer to average or higher earnings would. At that time Supplementary Benefit (SB) for pensioners below 80 was fractionally above the basic pension. Anyone with only the basic pension, or with only a partial pension, would have it topped up to this level (shown by the cross-hatched area in the diagram). But - apart, again, from the important complication of Housing Benefit - the effect of the system was that beyond quite a low level, people could benefit in full from any savings they had made through additional private pensions.

Through the 1950 s to the 1970s, a key debate was that many people did not actually have an earnings-related pension of the kind illustrated at the top of the diagram, or as given through continental social insurance systems. After twenty years of attempts, Barbara Castle's State Earnings Related Pension Scheme (SERPS) started in 1978. The result, for its greatest beneficiaries, who retired in 1998, is shown in Figure 5, again greatly simplified. By then, the basic pension, linked only to prices, had fallen to only 17 per cent of average earnings. But people could - under the accelerated accrual rules that then applied - have accumulated a full 'Additional Pension' (AP) under SERPS worth a quarter of their uprated earnings over the previous 20 years. For those with a private occupational pension, they would most likely have 'contracted out' of SERPS in return for lower NICs when at work. Their total private pension would have two parts - the equivalent of the Additional Pension, and the rest (shown here as the private pension). Meanwhile Income Support (IS), as the safety net was now called, had fallen to 18 per cent of average earnings - a wider gap than before above the basic pension.

Note that what the combination of SERPS and the Thatcher government's abandonment of uprating with earnings growth had achieved was to lower the 


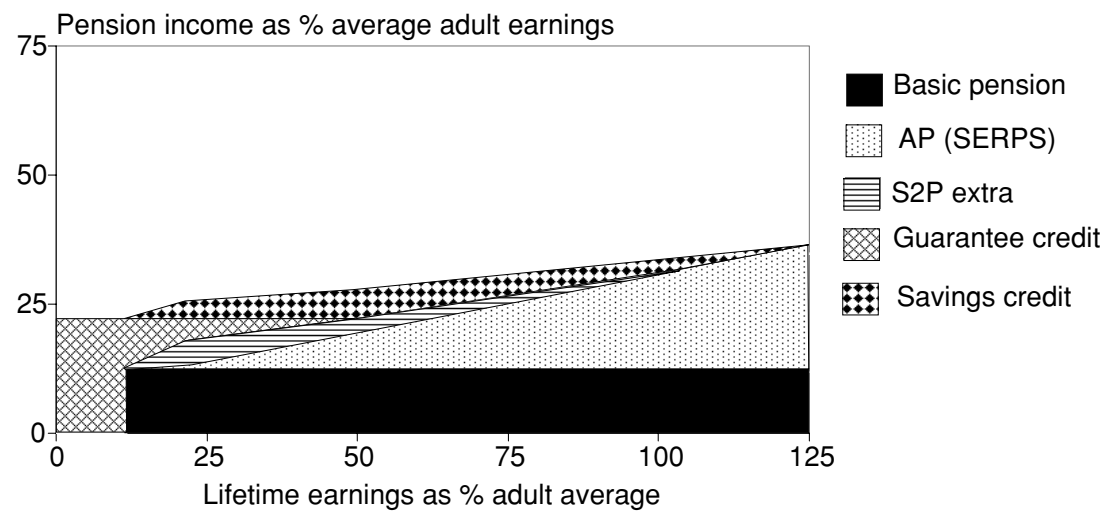

Figure 6(a). Retiring 2018 (without private pension).

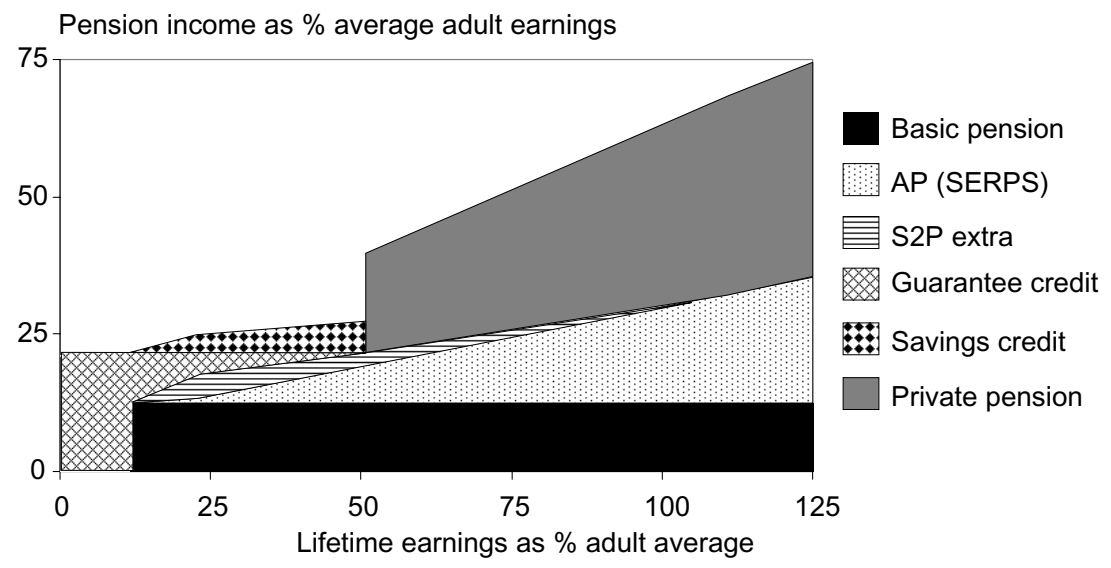

Figure 6(b). Retiring 2018 (with private pension).

relative cost of the basic pension, making room for the cost of the Additional Pension without overall pensions spending growing at all in relation to national income, despite there being more recipients. But this was at the cost of those with low lifetime earnings, who lost more from the fall in the relative value of the basic pension than they gained from SERPS. For later generations of retirees, the situation would be worse, as SERPS was made less generous for them by changes in 1988.

New Labour has tried to grapple with this in three ways, as Figures 6 (a) and (b) show. These give the - again simplified - position for a single person retiring around 2018. Under the reforms, a further part of what will come from the state (the 'savings credit' part of the new Pension Credit) is affected by whether any private pension is received, so Figure 6 (a) shows the position for someone with 
no private pension at all, and Figure 6 (b) the position if there is a private pension of the kind shown before.

By 2018, a price-linked basic pension would be only 12 per cent of average earnings ${ }^{9}$ (although now going to some with lower relative earnings than would have qualified before), and the earnings-related addition will be (mostly) based on 20 per cent of average lifetime earnings. This leaves very low state pensions for those earning below two-thirds of average earnings over their lifetime. In response, the government has boosted SERPS - now renamed the State Second Pension ( $\mathrm{S}_{2} \mathrm{P}$ ) - for people earning below $\mathfrak{E}_{10,500}$ in 2002 terms, with some gains higher up as well. The effect of this is shown in the diagrams by the horizontally shaded addition ('S2P extra') to what would previously have been given through the SERPS Additional Pension. The impact of these reforms phases in gradually by 2050 , but by 2018 the reform will already begin to flatten out entitlements for those below half average earnings.

The government has also increased the means-tested minimum for pensioners - renaming it first as the Minimum Income Guarantee or MIG, but now as the 'guarantee credit' - back up to 21 per cent of average earnings. The diagram shows that for those with less than half of average earnings, the total of the basic pension, the Additional Pension, and the State Second Pension top-up is not quite enough to get a low earner clear of the MIG at the moment of retirement in 2018.

The third reform was the Pension Credit introduced in October 2003. Under this, people with small occupational or additional pensions above the basic pension get a little extra - the 'savings credit' (shaded with diamonds in the figures) - above what was the MIG, so that they do gain something from their additional self-provision (but subject to a withdrawal at a rate of 40 per cent on any excess of income over the level of the guarantee credit). Someone with no private pension will still receive savings credit in respect of any State Second Pension rights (under old or new rules), so total state pension rights in the absence of any private pension are flattened further.

Without any private pension at all, the 'savings credit' element extends beyond those with average earnings, potentially extending means-testing over a much wider range than before (but at a lower withdrawal rate than the 100 per cent under the old MIG). As can be seen in Figure 6 (b), however, even a relatively small private pension is enough to remove entitlement to the savings credit - the extension of means-testing is potentially wide, but quite shallow.

By 2038 , the basic pension will be even lower ( 8 per cent of average earnings) but the new State Second Pension will be more fully phased in. This creates the position shown in Figure 7 (a) for the case where there is no private pension, and in 7 (b) for the case where there is for those above half average earnings. As with the diagrams for 2018, these projections assume that both the basic pension and the point at which people are credited into the system continue to be 


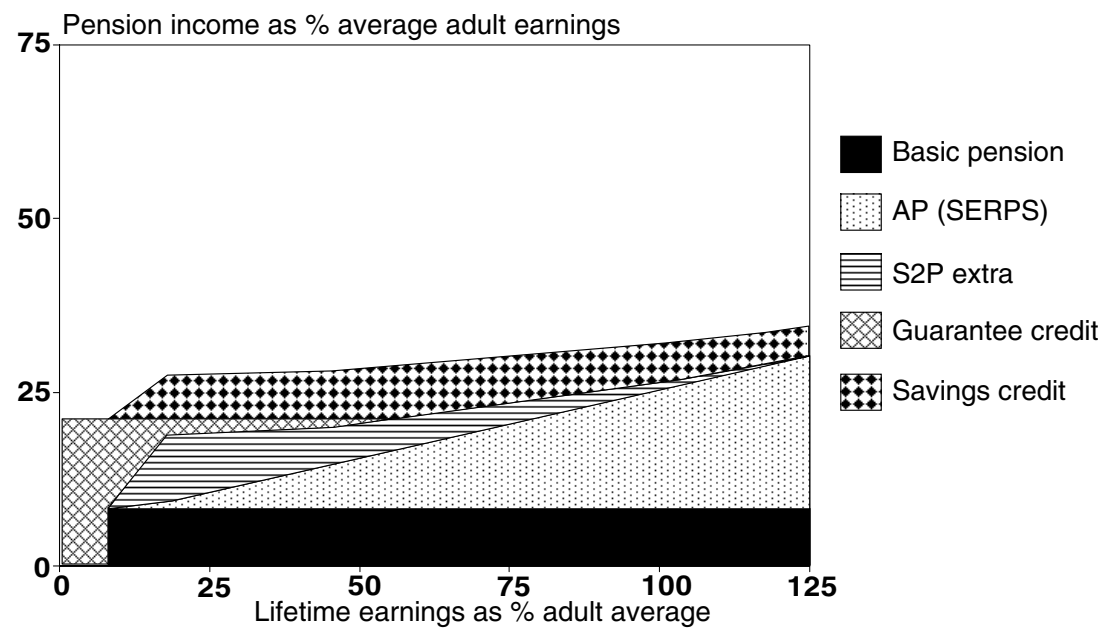

Figure 7 (a). Retiring 2038 without private pension.

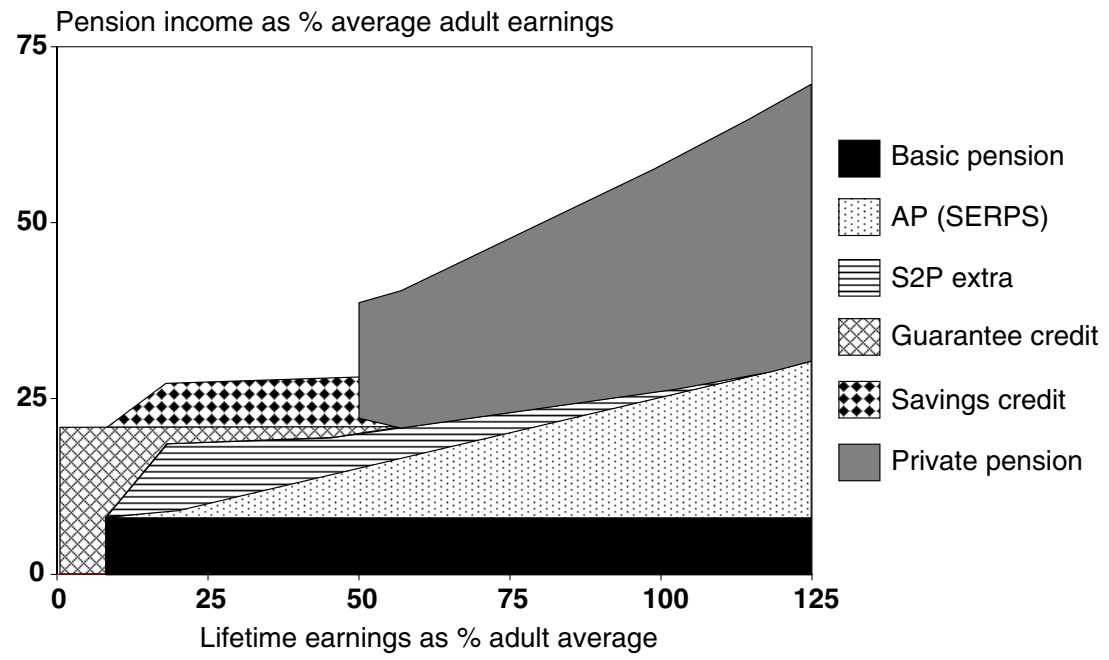

Figure 7 (b). Retiring 2038 with private pension.

price-linked..$^{10}$ The effect of the State Second Pension top-up is again almost, but not quite, enough to carry people clear of the level of the guaranteed minimum at the point of retirement.

One net effect of all of these reforms is as illustrated in Figure 8. This compares the total state support given on retirement to those with different lifetime earnings levels in 1978, 1998 and 2038. In 1978, this was almost flat at 25 per cent of average earnings - single people received much the same from the state whether 


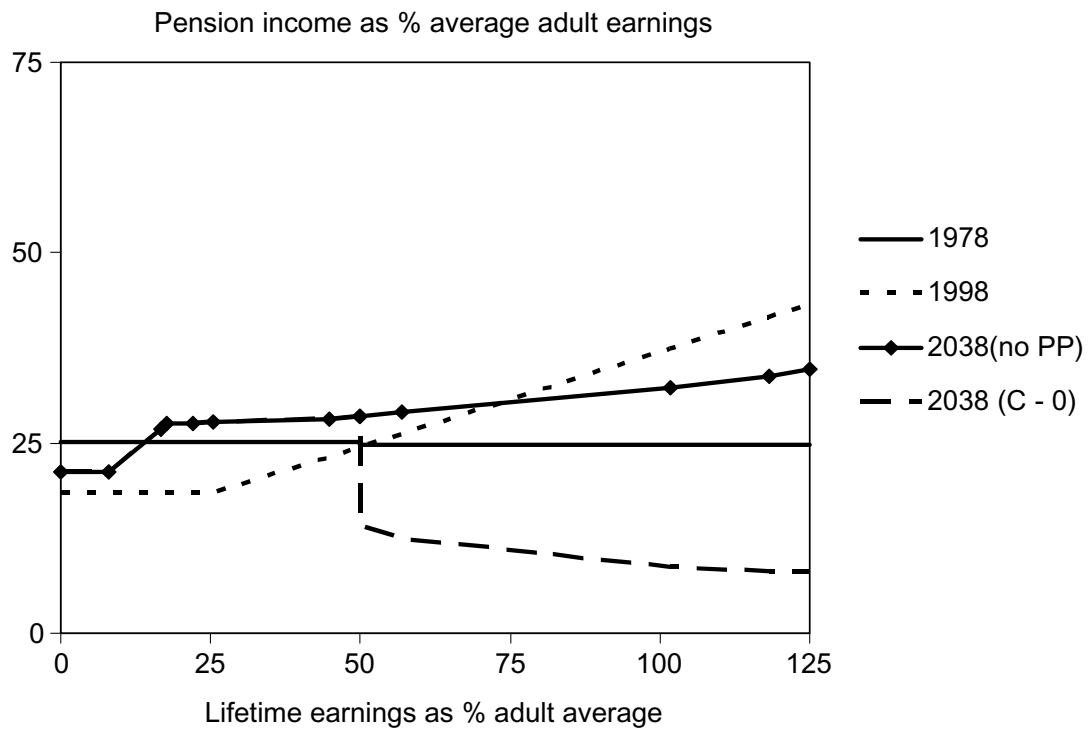

Figure 8. State support: retiring 1978-2038.

they had little private income and were receiving Supplementary Benefit or had private pensions on top of the basic pension. By 1998 those with lifetime incomes below half the average would have received less from the state than this (as the relative values of the MIG and basic pension had fallen), but those above would receive more (from SERPS).

Two lines are shown for 2038. For someone without a private pension, state support would rise from around 27 per cent of average earnings for those with all but the lowest earnings to nearly 35 per cent for those with the highest earnings shown. The result of 60 years of reform would be a return towards the point we began from in 1978, with total support again nearly flat, although at a slightly higher level in relation to future average earnings at the point of retirement (but lower later on in retirement as such benefits are planned to be price-linked, whereas in 1978 the reasonable assumption would have been that they would be earnings-linked after retirement). The end result when the reforms are fully phased in by 2050 is effectively to unwind Barbara Castle's attempt to turn Britain's state pensions into an earnings-related system along continental lines.

But how does this cost the state the same proportion of national income as now if there are going to be nearly 60 per cent more people over 65 in relation to the working age population? The often unappreciated answer lies in the fourth line - the cost to the state for those who are in private pensions and are 'contracted out' of the State Second Pension (as most are). This is much lower-partly because 
of the way in which those with significant private pensions will not benefit from the Pension Credit, but also because contracted-out private pensions pay part of what would otherwise come from the State Second Pension. In public finance terms, through the sacrifice of lower tax revenue today - achieved by 'contracting out rebates' - we are trying to stabilise the future costs of state pensions, despite the ageing population. ${ }^{11}$ The reward for today's fiscal sacrifice is that private pensions are intended to pick up part of the cost of future pensions that would otherwise have been carried by the state.

\section{Are the reforms likely to survive?}

What these plans are intended to achieve is quite neat: to return state support to something much closer to a flat rate system, with more generous support for low earners than in recent years, but to do so while keeping overall spending to a fixed share of GDP despite an ageing population.

Despite this, it seems unlikely that the reforms as presented here will survive intact. First, the combination of the different parts of the future state system described in the previous section is, to say the least, rather hard to explain simply. Even before the full changes including the Pension Credit came in, few people claimed that they understood pensions well. For instance, in 2002 only 13 per cent of working age respondents said that they had 'a good knowledge of pensions issues' and only 37 per cent 'a reasonable, basic knowledge' (Mayhew, 2003: Table 4.1). Nearly half, 49 per cent, said they only knew 'a bit about what concerns me' or knew 'little or nothing' (with slightly higher proportions in these categories than in 2000).

This lack of understanding, particularly about the interactions between state and private pensions is potentially problematic, as people's beliefs about what the state will provide affect their decisions about what they should add privately. For instance, some people might be unaware of the later potential effects of meanstesting, carry on contributing towards a small pension, but then later resent the fact that this ended up making them little better off in retirement. Alternatively, others might believe that they were likely to be caught by the spread of meanstesting and so reduce their pensions saving, even though a small private pension would actually carry them clear of the means-test, leaving the return on saving unaffected at the margin.

Second, while current understanding is very foggy, people do know that there is a flat-rate basic state pension and have a rough idea of its level (Hedges, 1998). The emerging system is in fact designed to mimic something not unlike a flat rate pension of more than 25 per cent of average earnings, but the part that people understand is planned to fall to a third or less of this total. Most people under 40 interviewed in 1998 no longer counted on getting a state pension at all. This is not popular. As Hedges summarised his 1998 research: 
Hardly anyone wants the state to withdraw. They not only feel that obligations to those who have already 'paid in' should be honoured, but beyond that the great majority of participants would prefer the state to stay in the pensions business long-term (1998: 2).

Current plans do not, in fact, mean that the state is getting out of pensions, but that is not what people believe. This does not seem good salesmanship.

Third, as others have discussed in some detail (Rake et al., 1999; Agulnik, 1999; Falkingham and Rake, 1999), the effect shown in Figures 6 and 7 for 2018 and 2038 that the state second pension will almost (but not quite) get people clear of the guarantee level only applies at retirement. After that, during retirement, state pensions are linked to prices only, while the means-tested minimum is planned to rise with earnings. Ten to fifteen years into retirement many with small pensions would be pulled into sharper means-testing. Here the new Pension Credit will help - but only by spreading shallower means-testing over a wider range. The same problem will apply even at the point of retirement after the 50 years phase-in of the new system in 2051, as the base of the whole system - the basic pension slips further in relative value.

It is too early to tell what the effect of the recent batch of reforms on public beliefs, understanding and behaviour will be, but it looks unlikely that we have reached the end of the journey.

On the other hand, a simple 'Back to Beveridge' restoration of a more valuable and earnings-linked basic pension does not look likely either, despite its many advocates. Compared with current plans, that would obviously mean significantly higher future spending. ${ }^{12}$ That might be seen as the inevitable consequence of a growing elderly population, but much of the benefits of that spending would accrue to those with higher, not lower, lifetime earnings who would be eating their cake through lower contracted out NICs now, but still having it through higher pensions later on. ${ }^{13}$ Those below two-thirds of average earnings - including many women - would gain little.

The cost of restoring earnings indexation of the basic pension could be kept down by allowing the relative value of the means-tested minimum to fall. ${ }^{14}$ There would be some low-income gainers from such a change, those who claim the basic pension, but not means-tested supplements to it. ${ }^{15}$ However, the majority of low-income pensioners would lose out by comparison with current plans, as the relative value of the means-tested minimum fell towards the current (lower) level of the basic pension. At the same time, higher-income pensioners would tend to gain by comparison with current plans, as they would benefit from the higher basic pension, without having means-tested benefits to lose.

\section{An alternative way forward for state pensions?}

The fundamental aims of any reform of state pensions remain simple to state: keeping costs to acceptable levels (or making inevitable costs acceptable); 


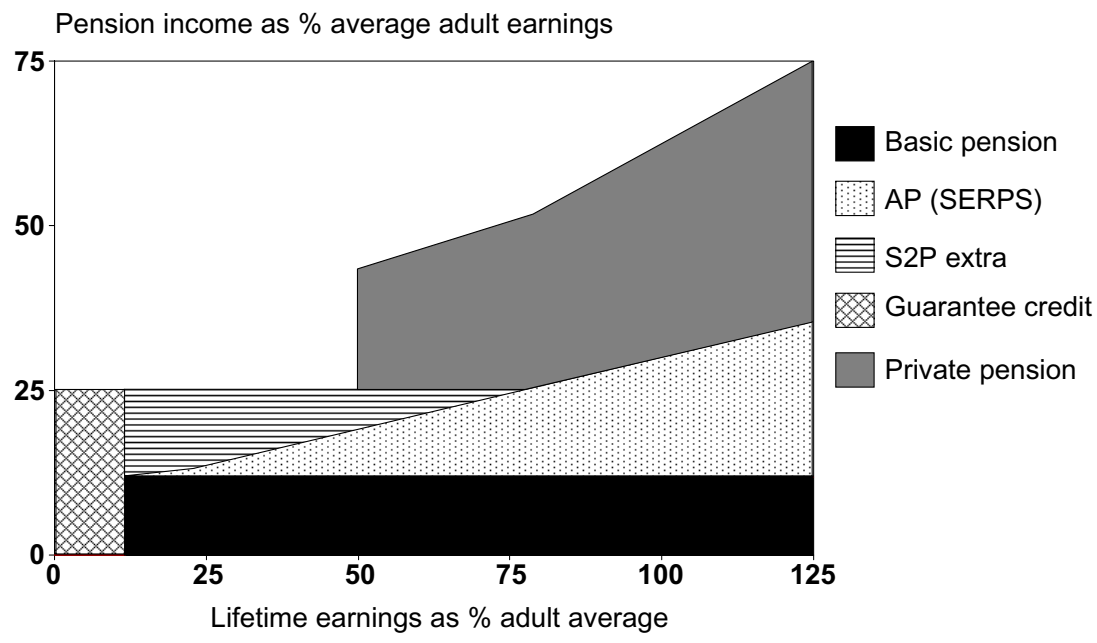

Figure 9. Integrating State Second Pension and Pension Credit (2018)?

ensuring that those entitled to support receive it; minimising disincentives to self-provision; avoiding adverse distributional effects (the direction of which will depend, of course, on ideological taste); and promoting the public acceptability and durability of the system. The difficulty is that such apparently reasonable aims conflict. Current plans keep costs down, but at the cost of significant complexity, and of a wider spread of means-testing, with potential problems for incentives and take-up. Simply increasing the value of the basic pension would have significant costs, and would do little for many poor pensioners. Keeping costs down and reducing disincentives by making means-testing less generous would make many lower-income pensioners worse off than under current plans.

There are many possible reform options, and no space here to review them. The discussion above does, however, suggest one modification of current proposals that might navigate through some of the conflicting objectives. Perhaps surprisingly, it would involve being more honest and explicit about what recent reforms are trying to achieve - getting a minimum contributory state pension which people can build on as close as possible to the current means-tested minimum, while not giving extra to those with higher lifetime earnings. In effect recent reforms are an attempt to restore something closer to Beveridge's flatrate payments to pensioners by other means, and to unwind Britain's belated excursion into earnings-related state pensions. If we were explicit about it, the next stage of reform could be an alignment or integration of the State Second Pension and the minimum guaranteed by the Pension Credit.

Figure 9 illustrates what such a system might look like for those retiring in 2018. This shows what would result if the State Second Pension top-up was set not 
as a complicated function of accrued earnings, but simply to bring the total of the basic pension and any rights through SERPS up to a minimum level at the point of retirement. ${ }^{16}$ The minimum is shown here at 25 per cent of average earnings for an individual by way of illustration. ${ }^{17}$ As time went by, the basic pension would become less important and the top-up more important. Eventually the total would become completely flat rate - except that the 'Additional Pension' part could continue to perform the functions of both pre-funding future costs (through contracting out) and ensuring that those who can afford to provide for part of the costs of this minimum do so through their own contributions. Once calculated at retirement, the total (either from the state or promised in return for contracting out) could be adjusted each year to keep up with growth in general incomes.

An outcome of this kind would have several advantages:

- A clear message could be given that the total 'state pension' would be at least the set percentage of earnings (except to the extent that people had chosen to fund part of this themselves in return for lower contributions). ${ }^{18}$

- Eventually the 'state pension' would again become a flat rate amount. Indeed rules on future accrual of the State Second Pension could be adapted to accelerate this process.

- This amount could be maintained both over time and after retirement, so that the part of pensioners' living standards based on it would not slip back in relative terms.

- Over time, the effect of the price-linked shadow Lower Earnings Limit would mean more and more of those with relatively low earnings being credited in, as well as carers for children or disabled people, or those unable to work because of disability. In effect, it would turn into a 'participation pension' rather than a contributory pension. ${ }^{19}$ If the recommendations of the recent House of Commons Social Security Committee report (2000) on the contributory principle were followed, and the lower limit for entitlement frozen in cash terms, this process would be accelerated.

- Crucially, with the minimum state pension set at retirement, most people's private pension receipts would return to being an add-on to the flat rate state pension (apart from any part which was being provided privately in return for contracting out rebates on NICs). The spread of means-testing within the state pension system would be reduced, so that at the margin people would retain the benefits of their additional saving, restoring much clearer incentives for additional private provision.

\section{National insurance as a whole}

What would such an outcome mean for the future of the National Insurance system? Perhaps surprisingly, given the discussion at the start of the article, it 
would leave it with a future - albeit in a rather different form from that envisaged by Beveridge or familiar to people used to continental social insurance.

The system we have today results from a series of battles that the 'contributory principle' has lost over the last 60 years. Contribution-based entitlements excluded too many, and benefits related in size to contributions have not taken root. Restoring what was intended by Barbara Castle's reforms in the 1970 seems politically out of the question. But equally, outright abolition of the system also seems politically unlikely, particularly given that the overwhelming bulk of it relates to pensions, accrued rights to which last for decades. However, as it stands the system is widely misunderstood and very hard to explain.

As far as pensions are concerned, the suggestion above is that one way forward would be to be explicit about what recent reforms are trying to achieve and to adapt them to allow a clearer message about their effects. At the heart of this would be explicit acceptance that one of Beveridge's principles - of flat rate benefits - has proved of enduring - even strengthening - popular appeal.

The recent invention of the 'shadow' Lower Earnings Limit giving pension rights to low earners without making contributions comes on top of credits for people in education, training, caring and in other recognised circumstances. Recent reforms to maternity allowances have equally credited in low earners (albeit with different rules). These reforms open up a new way of looking at 'National Insurance'. It could become a system based on 'participation' records, not 'contribution' records.

Of course, once looked at this way, the question of 'what is participation?' arises. For instance, if low paid work without contribution counts, as it now does for the State Second Pension, why not self-employment (perhaps with higher contributions than now)? Should caring for children of any age (as in the basic pension) or only those aged under six (as in the second pension) count as participation? A series of questions of this kind would have to be answered, but in answering them we would be making explicit choices which are already being made, but in obscurity.

There is then a choice for the remaining sixth of National Insurance benefits. One option would be to argue that times have changed since social insurance was developed to cope with the 'risks' that 'interrupted' earnings through unemployment, sickness, and old age. Today, looking on retirement as a 'risk' seems anomalous: in today's labour market, retirement is anticipated and planned for. This puts it in a different category from the others, and could be argued to make the case for dissociating pensions from the other 'insurance' benefits, absorbing the latter into the rest of social security. National Insurance Contributions could then be seen more clearly as what they mainly are, 'state pension contributions' (or 'state pension and health contributions'). Non-means tested Jobseeker's Allowance could become more clearly run together with other 
benefits and measures for the unemployed, and maternity allowances similarly absorbed into the rest of social security.

This separation would match other recent reforms to benefits for the working age population. But it does not solve all the problems. In particular, where would Incapacity Benefit lie: as part of unemployment benefits, and so with working age social security, or treated as effective early retirement, and so part of the pensions system? Many of those receiving it may indeed have started retirement, but for others it has been damaging to treat them as never likely to work again. Drawing this boundary is not straightforward.

An alternative would be to combine the direction of reform to pensions discussed above with the recommendations made by the House of Commons Social Security Select Committee (2000) when it examined the contributory principle. This was to extend the recent maternity allowance reforms - with entitlement depending on a (low) level of previous earnings rather than contribution records - to the other insurance benefits. In effect, this would maintain the scope of National Insurance, but with it all run on a 'participation' system, abandoning the residual (and increasingly obscure) remnants of links to actual contributions. This would, however, cost more, and the present government showed little enthusiasm for it in its response to the committee. Taking the cost on would require a judgement that a reinvigorated National Insurance system of this kind could be successfully marketed politically - this might be optimistic in the light of recent history.

\section{Conclusion}

The Beveridge Report celebrates its 65th birthday in 2007. A prior expectation given the decline of National Insurance in recent years might have been that this could mark a good moment for retirement of the system it led to. But this might not match the spirit of the times. Under age discrimination legislation compulsory retirement ages will, after all, be illegal by 2007. 'Flexible retirement' is on its way in. Similarly, some of the original principles of National Insurance have undoubtedly already gone, and others are on their way out, but those which underpin an inclusive, flat rate system for large parts of our social security system may still have some working life in them yet, if we could pull them clear of the tangles of what we have now.

\section{Notes}

1 In 2003-04 the contribution rate for employers was 12.8 per cent on all earnings above the primary threshold. For employees, the rate was 11 per cent up to the Upper Earnings Limit

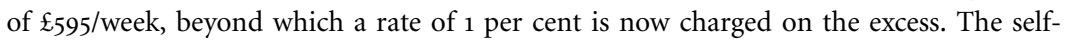
employed pay a small flat rate amount as well as a low percentage (8 per cent in 2003-04) of profits between the threshold and the upper limit, and 1 per cent of profits on the excess over that. 
2 Conditions governing Statutory Maternity Pay and Statutory Sick Pay are closely related to the rules of National Insurance, but are paid by employers, rather than through the benefit system.

3 That is, people gain from any additional insurance or pension coverage they organise for themselves, in contrast to the position with means-tested benefits, where part or all of the benefit may be lost. Under any kind of social security cover, the fact of that coverage may mean, of course, that people decide that they do not need any more, whereas in the absence of state protection, they might have organised some for themselves.

4 For a summary list, see Hills (2003, table 1). For more detailed discussion, see the contributions to Hills et al. (1994), particularly those by Glennerster and Evans, Lowe and Veit-Wilson. For overall accounts of the development of social security in the UK since 1945, see Hill (1990), or relevant chapters of Timmins (1995) or Glennerster (2000).

5 The existence of a state benefit system may in itself affect the labour market, with bargaining behaviour affected by the existence of, say, benefits during times of unemployment or retirement. What is harder to argue in the current UK system is that there would be much recognition of the way such rights are 'earned' through contributions in a different way from other benefits.

6 The relevant questions in the survey do not explicitly put the argument that, for instance, those with higher earnings have previously paid more in National Insurance Contributions (or tax) and so might be 'entitled' to higher benefits. None the less, they show little sign of an appetite for income replacement as an aim of the state system.

7 It takes account of the 2001 Census and the Pension Credit introduced in October 2003, but not of unfunded public service pensions, the net value of tax reliefs for occupational and personal pensions, or NIC rebates for those contracted out of the State Second Pension.

8 For simplicity, people are assumed - through one route or another - to be entitled to a full basic pension if their earnings are at or above the Lower Earnings Limit at the date of retirement. With the Lower Earnings Limit effectively price-linked, this brings those with progressively lower lifetime earnings into entitlement over time. However, for other parts of the state pension system, the diagrams take account of the way entitlements depend on the relationship between earnings and the Lower Earnings Limit (and other parameters of the system) at the date of accrual of rights.

9 Assuming real earnings growth of 2 per cent in line with recent government projections.

10 The Upper Earnings Limit is assumed to stay above 125 per cent of average earnings. Recent policy on the level of the Upper Earnings Limit has been ambiguous, having been pricelinked for many years, and so falling in relation to average earnings, but then increased significantly in 2000 and 2001. If the limit were linked only to prices, it would fall to 92 per cent of average earnings by 2018, and further still by 2038. This would limit - and further flatten - accruals of rights to state pensions for those with higher earnings levels, below those shown in the diagrams. It would also have major - and perhaps unlikely implications for the structure of direct taxation unless there were further changes to the treatment of earnings above the limit.

11 Whether the terms of this deal are a good one for the state or for those contracting out is rather complex, and depends on both personal circumstances and future developments. Ward (2002) quotes estimates that for those in 'defined benefit' occupational schemes, every $\mathfrak{E}_{1}$ of rebate paid out in the late 1990 os only generated 88 pence-worth of later savings in SERPS costs.

12 Of course, as with any system, costs could be cut by raising state pension age (to the extent that savings were not offset by rising spending on other benefits going to those who did not continue working). What should happen to state pension age goes beyond the scope of 
this article, which is concerned with the structure of support. See Pensions Policy Institute $(2002,2003)$ for an overview of issues around state pension age.

13 Unless a government were to take the highly contentious step of reneging on already accrued rights to the State Second Pension (as opposed to changing rules for future accrual).

14 As implied, for instance, by recent Conservative Party plans for pensions (Willetts and Yeo, 2003).

15 Official estimates are that between 24 and 32 per cent of pensioners entitled to the Minimum Income Guarantee failed to claim it in 2000-01. Non-claimants tend to have lower entitlements than those who do claim, so the amount of available cash left unclaimed was estimated at 14-22 per cent (DWP, 2003).

16 See Curry (2002) for a more detailed proposal for a 'State Pension Guarantee' along similar lines.

17 This is close to what we are heading for on average by 2018 and 2038, for those not contracted out, allowing for assumed post-retirement indexation only with prices under current plans. Here post-retirement indexation of the total topped-up to is assumed to be earnings-linked. What level was actually set would depend on what costs were seen as acceptable, and on other issues such as whether state pension age remained at its equalised 65, which are beyond the scope of this paper. The logic of the argument here also suggests that the minimum pension should be set on an individual basis (so that a couple with full 'participation' records would be entitled to a minimum totalling 50 per cent of average earnings between them). As the Pension Credit is means-tested on a joint basis for couples, this would mean that there would be less of an offsetting saving from its absorption into the State Second Pension for them than for single people, which would also increase net costs for any given minimum.

18 For those who had 'contracted out', what they would get from the state might be lower, under the rules at the time reflecting their lower contributions (usually equivalent to the 'AP' part of Figure 9). As discussed above (note 11), while the impact of this on entitlements can be defined relatively clearly, whether or not the trade-off between lower contributions and lower entitlement was a 'good deal' for either side is much harder to calculate. For simplicity, there are arguments in favour of abolishing future contracting out, but that would have significant cash flow effects on government (positive initially, but leading to higher spending later on).

19 This would create, in effect, a limited form for those above pension age of the 'participation income' suggested by Atkinson (1995: ch. 15) for the whole population, or a step towards an 'Old Age Basic Income' (Atkinson, 2002). Note that the form of top-up suggested here differs from - and is less ambitious than - his (1995: ch. 16) suggestion of a 'Minimum Pension Guarantee', as the minimum state pension suggested here takes account of compulsory second pension accumulation as well as the basic pension.

\section{Acknowledgements}

Funding for the research for this paper from the Economic and Social Research Council as part of its support for CASE is gratefully acknowledged. The views expressed in it are the author's rather than representing those of CASE, ESRC, or any other body. An earlier version of material in this article formed part of the James Seth Memorial Lecture at the University of Edinburgh in January 2003. The author is grateful to Michael Adler and the School of Social and Political Studies for the invitation to give the lecture, and for very helpful comments and suggestions from its audience and from participants in subsequent seminars at both the University of Edinburgh and the London School of Economics. He is also grateful for helpful comments on 
the original text from two anonymous referees, and from Tony Atkinson, Fran Bennett, Jochen Clasen, Chris Curry, Julian Le Grand, Abigail McKnight, David Piachaud, and Sally Witcher. Figures 2 and 3 are Crown Copyright, drawn from the documents cited.

\section{References}

Agulnik, P. (1999), 'The proposed State Second Pension and National Insurance', in 'Partnership in Pensions? Responses to the Pensions Green Paper', CASE paper 24, LSE, London.

Atkinson, A. B. (1995), Incomes and the Welfare State, Cambridge: Cambridge University Press. Atkinson, A. B. (2002), 'How basic income is moving up the policy agenda: news from the future', paper given at the Ninth Congress of the Basic Income European Network, Geneva, September (mimeo).

Beveridge, W. (1942), 'Social insurance and allied services', Cmd. 6404, HMSO, London.

Clasen, J. (2001), 'Social insurance and the contributory principle: a paradox in contemporary British social policy', Social Policy and Administration, 35: 6, 641-57.

Curry, C. (2002), Reforming the State Pension System: The State Pension Guarantee, London: Association of British Insurers.

Department for Work and Pensions [DWP] (2002), 'Simplicity, security and choice: working and saving for retirement', Cm 5677, The Stationery Office, London.

DWP (2003), 'Income related benefits: estimates of take-up in 2000/2001', DWP, London.

Dilnot, A., Kay, J. and Morris, C. N. (1984), The Reform of Social Security, Oxford: Oxford University Press.

Falkingham, J. and Hills, J. (eds.) (1995), The Dynamic of Welfare: The Welfare State and the Life Cycle, Hemel Hempstead: Harvester Wheatsheaf.

Falkingham, J. and Rake, K. (1999), " "Partnership in pensions": delivering a secure retirement for women?', in 'Partnership in Pensions? Responses to the Pensions Green Paper', CASE paper 24, LSE, London.

Glennerster, H. (2000), British Social Policy since 1945, second edition, Oxford: Blackwell.

Hedges, A. (1998), 'Pensions and retirement planning', Research Report No. 83, Department of Social Security, London.

Hedges, A. and Bromley, C. (2001), Public Attitudes towards Taxation, London: Fabian Society.

Hill, M. (1990), Social Security Policy in Britain, Aldershot: Edward Elgar.

Hills, J. (2001), 'Poverty and social security: what responsibilities? Whose rights?', in A. Park, J. Curtice, K. Thomson, L. Jarvis, C. Bromley and N. Stratford (eds.), British Social Attitudes: The 18th Report, London: Sage.

Hills, J. (2003), 'Inclusion or insurance? National Insurance and the future of the contributory principle', CASE paper 68, LSE, London.

Hills, J., Ditch, J. and Glennerster, H. (eds.) (1994), Beveridge and Social Security: An International Retrospective, Oxford: Oxford University Press.

HM Treasury (2002), 'Long-term public finance report: an analysis of fiscal sustainability', HM Treasury, London.

House of Commons Social Security Committee (2000), 'The contributory principle', Fifth Report, 1999-2000, The Stationery Office, London.

Mayhew, V. (2003), 'Pensions 2002: Public attitudes to pensions and saving for retirement', DWP Research Report 193, Corporate Document Services, Leeds.

Park, A., Curtice, J., Thomson, K., Jarvis, L. and Bromley, C. (eds.) (2002), British Social Attitudes: The 19th Report, London: Sage.

Pensions Policy Institute [PPI] (2002), Raising State Pension Age: Are We Ready?, London: PPI. PPI (2003), Raising State Pension Age: An Update, London: PPI.

Rake, K., Falkingham, J. and Evans, M. (1999), 'Tightropes and tripwires: New Labour's proposals and means-testing in retirement', CASE paper 23, LSE, London.

Stafford, B. (1998), 'National insurance and the contributory principle', DSS Social Research Branch In-house Report 39, Department of Social Security, London.

Timmins, N. (1995), The Five Giants: A Biography of the Welfare State, London: Harper Collins. 
Titmuss, R. (1955), 'The social services', James Seth Memorial Lecture, University of Edinburgh, March.

Titmuss, R. (2001), 'Welfare state and welfare society', in T. Burchardt, P. Alcock, J. Hills, H. Glennerster and A. Oakley (eds.), Welfare and Wellbeing: Richard Titmuss's Contribution to Social Policy, Bristol: Policy Press (originally published in 1967).

Ward, S. (2002), 'Public-private partnerships in pensions policies', in C. Glendenning, M. Powell and K. Rummery (eds.), Partnerships, New Labour, and the Governance of Welfare, Bristol: Policy Press.

Webb, S. (1994), 'Social insurance and poverty alleviation', in S. Baldwin and J. Falkingham (eds.), Social Security and Social Change: New Challenges to the Beveridge Model, Hemel Hempstead: Harvester Wheatsheaf.

Willetts, D. and Yeo, S. (2003), A Fair Deal for Everyone on Pensions, London: Conservative Party. 